\title{
Znaczenie reklamy w postrzeganiu i kształtowaniu decyzji zakupowych konsumentów z gmin wiejskich województwa podkarpackiego
}

\section{The Importance of Advertising in the Perception and Shaping of Purchasing Decisions of Consumers from Rural Communes of the Podkarpackie Province}

\begin{abstract}
Synopsis. W artykule scharakteryzowano upodobania konsumentów $\mathrm{z}$ gmin wiejskich woj. podkarpackiego, dotyczące rodzaju i odbioru reklam, a także ich wpływ na realizację zakupu towarów. W interpretacji empirycznych wyników badania, przeprowadzonego wśród 500 konsumentów, wykazano zainteresowanie rodzajami form i elementów reklam, najskuteczniejsze przekazy reklamowe decydujące o zakupie towarów, rodzaj dóbr i usług nabywanych pod wpływem reklam, jak również stosunek do reklamowanych nowych produktów wchodzących na rynek. W kontekście przeprowadzonej analizy należy stwierdzić, że najważniejsze znaczenie dla mieszkańców obszarów wiejskich woj. podkarpackiego miały reklamy telewizyjne i internetowe, reklamy cechujace się oryginalnością oraz walorami estetycznymi, w tym zwłaszcza muzyką. W podejmowaniu decyzji zakupu towarów reklamy miały wpływ w przypadku $46 \%$ badanych. Bardziej pozytywne nastawienie do reklam i podatne na nie były kobiety.
\end{abstract}

Slowa kluczowe: konsumenci, reklama, gminy wiejskie.

\begin{abstract}
The article describes the preferences of consumers from rural communities of the Podkarpackie Province, regarding the type and reception of advertisements, as well as their impact on the purchase of goods. In the empirical interpretation of research results, conducted among 500 consumers, interest in various types and elements of advertising was pointed out, along with the most effective advertising messages determining the purchase of goods, type of goods and services purchased under the influence of advertising, as well as the approach to advertised new products being launched in the market. In the context of the analysis, it should be stated that the most important for the inhabitants of rural areas of the Podkarpackie Province were TV and internet advertisements, and advertisements characterized by originality and aesthetic values, especially music. The decisions to buy goods were influenced by advertisements according to $46 \%$ of respondents. Women were more positively-oriented towards advertisements and more susceptible to ads.
\end{abstract}

Key words: consumers, advertising, rural communities, purchasing decisions

JEL Classification: D12, M37

\footnotetext{
${ }^{1}$ dr hab., prof. UR. Wydział Ekonomii, Katedra Marketingu i Przedsiębiorczości, Uniwersytet Rzeszowski, ul. M. Ćwiklińskiej 2, 35-601 Rzeszów, e-mail: marketing@ur.edu.pl

${ }^{2}$ dr Wydział Ekonomii, Katedra Marketingu i Przedsiębiorczości, Uniwersytet Rzeszowski, ul. M. Ćwiklińskiej 2, 35-601 Rzeszów, e-mail: wszopin@ur.edu.pl
} 


\section{Wstęp}

Zarówno integracja europejska jak i globalizacja w XXI wieku współtworzą nowe uwarunkowania zachowań konsumentów (Małysa-Kaleta, 2010). Jako procesy dominujące w otoczeniu współczesnych konsumentów wywierają wpływ na stworzenie tzw. europejskiej kultury spożycia (Mazurek-Łopacińska, 2001). Nowe uwarunkowania wpływające na decyzje zakupowe konsumentów wiążą się między innymi z elementami wpływającymi na ich zadowolenie i satysfakcję dzięki nieograniczonemu dostępowi do informacji zawartych w reklamach: internetowych, telewizyjnych, radiowych, prasowych. W związku z nowymi uwarunkowaniami został wykreowany tzw. konsument nowej ery (Małysa-Kaleta, 2010), którego m. in. charakteryzują takie cechy jak: niezależność, zaangażowanie, odpowiedzialność, świadomość swoich praw zwłaszcza aktywne poszukiwanie informacji o ofercie rynkowej dóbr i usług, z wykorzystaniem różnych form reklamy.

Reklama, we współczesnych realiach gospodarczych wolnego rynku, jest zjawiskiem powszechnie występującym. Jej oddziaływanie na konsumentów jest zawsze aktualne, gdyż producenci dóbr i usług permanentnie wykorzystują tę formę promocji. Zasadniczym celem reklamy jest przekonanie jak największej liczby nabywców do zakupu określonych towarów. Jej zadaniem zdaniem Rudnickiego (2009) jest kreowanie postaw konsumentów, ich zmianę lub zwiększenie intensywności zachowań nabywczych. Funkcjami natomiast, które spełniają jest funkcja: informacyjna, edukacyjna, konkurencyjna oraz wspieranie sprzedaży dóbr (Gędek, 2013). Do konsumentów należy odpowiednie jej postrzeganie i wykorzystywanie w procesie decyzyjnym (Nowacki, 2013). Zdaniem Kozłowskiej (2014) pomimo osiagnięcia już pewnej wiedzy z zakresu wpływu reklamy na decyzje nabywcze konsumentów, w dalszym ciągu, wydaje się być ona niewystarczająca. Występuje zatem potrzeba kontynuowania badań w tym zakresie.

Uwzględniając zatem aktualność i znaczenie zagadnienia celem artykułu było określenie form i elementów reklam, które przyciagają uwagę i wywierają wpływ na decyzje zakupu dóbr mieszkańców gmin wiejskich woj. podkarpackiego.

$\mathrm{W}$ procesie odbioru reklam konsumenci są aktywni, ponieważ potrafią ignorować docierające do nich fakty, jak również poszukiwać ich, przekształcać, zniekształcać. Zgodnie z psychologia percepcji reklamy, duże znaczenie w jej odbiorze odgrywa sam obraz i sposób umieszczania w niej informacji (Doliński, 2010).

\section{Przebieg badania i charakterystyka próby}

Problem badawczy został przeanalizowany na podstawie pierwotnych źródeł informacji. Uzyskano je w wyniku, przeprowadzonych w 2017 roku, badania empirycznego z użyciem samodzielnie przygotowanego kwestionariusza ankiety, metodą wywiadu bezpośredniego ${ }^{3}$. Ankietyzacją objęto pięć gmin wiejskich województwa podkarpackiego. Respondentów, w liczbie 500 osób, dobrano bazując na zasadach doboru celowego, przeprowadzając wywiad wśród konsumentów kierujących się przy realizacji zakupów reklamą towarów oraz doboru nielosowego kwotowego (płeć, wiek). Według przyjętych kryteriów kobiety stanowiły $51 \%$, mężczyźni natomiast $49 \%$. Ankietowani reprezentowali

\footnotetext{
${ }^{3}$ Badania przeprowadzili studenci Wydziału Ekonomii Uniwersytetu Rzeszowskiego realizujący prace dyplomowe pod kierunkiem autorów artykułu.
} 
pięć grup wiekowych. Przedziały wiekowe 18-24 lat i 40-59 lat stanowily w równym stopniu po $24 \%$. Wiek $25-39$ lat dotyczył $20 \%$ badanych, a 60 lat i więcej-32\%. Należy podkreślić, że płeć i wiek jako czynniki demograficzne są jednymi z istotnych obiektywnych determinant kształtujących zachowania konsumentów (Sowa, 2010). Skale zjawisk oraz stopień ważności czynników sprawczych, podawanych przez osoby ankietowane, określono $\mathrm{w}$ procentach. $\mathrm{W}$ interpretacji wyników badania posłużono się metodą indukcyjno - dedukcyjną. Biorąc pod uwagę regionalny charakter wyników badania można je wykorzystać do porównania $\mathrm{z}$ danymi pochodzącymi $\mathrm{z}$ innych województw w kraju.

\section{Rodzaj reklam i upodobania badanych konsumentów dotyczące przekazów reklamowych}

We współczesnych realiach rynkowych stosowanych jest wiele form i coraz więcej różnorodnych elementów wykorzystywanych w przekazach reklamowych towarów. Celem takich działań jest nie tylko zainteresowanie ale przede wszystkim przekonanie i pozyskanie, bardzo wymagających konsumentów, do zakupu reklamowanych dóbr i usług. $\mathrm{Na}$ rysunku 1 przedstawiono odsetek wypowiedzi ankietowanych, dotyczących zainteresowania poszczególnymi formami przekazu reklamowego.

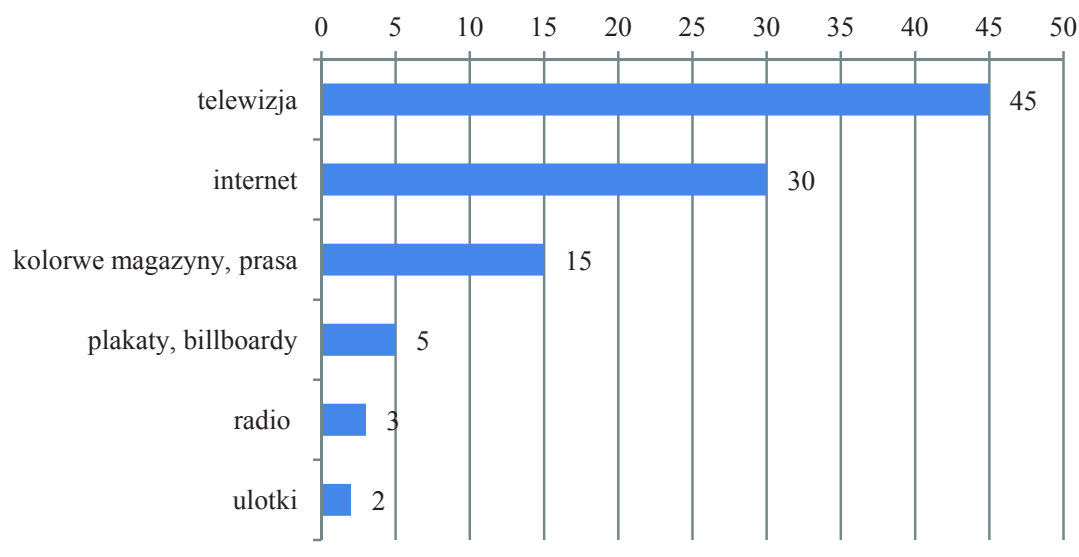

Rys. 1. Rodzaj form reklam wzbudzających zainteresowanie konsumentów (\% wskazań)

Fig. 1. Type of advertising forms arousing consumers' interest ( $\%$ of indications)

Źródło: obliczenia własne na podstawie przeprowadzonego badania ankietowego.

Ze struktury wypowiedzi wynika, że największy udział stanowili konsumenci zainteresowani reklamami telewizyjnymi. Jest to zjawisko zbieżne $\mathrm{z}$ występującymi w całej Polsce, na co wskazuje Paszko (2014), która zauważa, że reklama telewizyjna, mimo wzrostu popularności internetu i reklam internetowych, nadal cieszy się dużą popularnością w kraju. Bednarek (2014) natomiast podkreśla, że przychody z reklam telewizyjnych w Polsce należą do najważniejszych w Europie Środkowo - Wschodniej. Wynika to stąd, że większość ludzi ogląda różne programu telewizyjne, w związku z czym są równocześnie 
odbiorcami reklam emitowanymi przez zdywersyfikowane kanały tv. Na drugim miejscu uplasowały się osoby zwracające szczególną uwagę na reklamy zamieszczane w Internecie. Jest to wynik coraz powszechniejszego dostępu Polaków, także na obszarach wiejskich, do Internetu. Z badań zamieszczonych w Diagnozie Społecznej w 2013 roku wynika że dostęp do Internetu posiada 63,2\% Polaków (Bednarek, 2014). Prawie co siódmy badany interesował się reklamami występującymi w prasie i w kolorowych magazynach. Dla tej grupy wypowiadających się reklamy w prasie wzbudzały największe uznanie. Wśród badanych znikomy odsetek stanowili ci, którzy uwagę zwracali zwłaszcza na tego rodzaju nośniki reklamy jak: plakaty i billboardy oraz radio i ulotki.

Kolejnym analizowanym zagadnieniem dotyczącym zainteresowania reklamami, ankietowanej zbiorowości osób, była kwestia określenia najciekawszych, zdaniem wypowiadających się, przekazów reklamowych. Strukturę opinii na ten temat prezentuje rysunek 2.

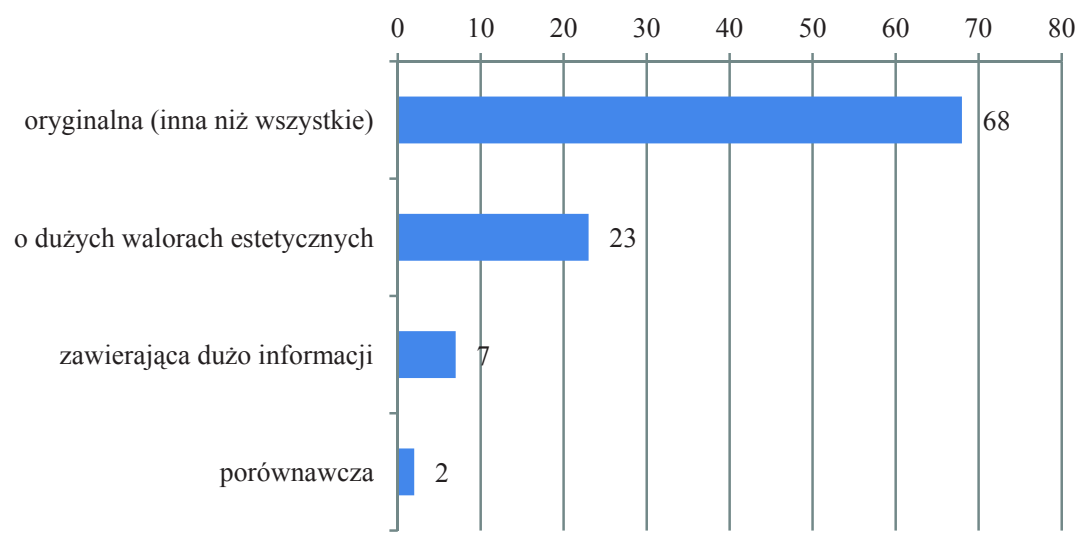

Rys. 2. Najciekawszy przekaz reklamowy w opinii badanych (\% wskazań)

Fig. 2. The most interesting advertising message in the opinion of respondents ( $\%$ of indications)

Źródło: obliczenia własne na podstawie przeprowadzonego badania ankietowego.

Na podstawie zaprezentowanych danych należy zauważyć, że zdecydowaną przewage stanowily osoby, zdaniem których, reklamy oryginalne są najciekawsze, gdyż są chętnie oglądane i utrwalane w pamięci odbiorców. Dla prawie co czwartego wypowiadającego się istotne były walory estetyczne, które stwarzaja miłą atmosferę i przyjemny nastrój, ukierunkowując konsumentów pozytywnie na reklamowane produkty. Co piętnasty ankietowany zwracał uwagę na reklamy charakteryzujące się wyczerpującym dla odbiorcy przekazem informacji o produkcie. Wśród ogółu badanych dla zaledwie $2 \%$ osób najciekawszymi okazały się reklamy porównawcze.

Sześć głównych elementów reklamy: muzyka, elementy wizualne, przekaz słowny, konkretne fakty, kolor i występowanie znanych osób było branych pod uwagę wśród ankietowanych pochodzących $\mathrm{z}$ gmin wiejskich. Największy udział stanowili odbiorcy reklam zwracający uwagę na muzykę. Należy zauważyć, że czynnik ten był także istotny dla 28\% ogółu Polaków (Nowacki, 2012). Dla co piątego najistotniejsze były elementy wizualne ten fakt podkreśla m. in. Doliński (2010), którego zdaniem zgodnie z psychologią 
percepcji reklamy, duże znaczenie w jej odbiorze odgrywa sam obraz. Przekaz słowny i podawanie konkretnych faktów były głównymi elementami zainteresowania w równym stopniu dla prawie co szóstego wypowiadającego się na ten temat. Elementami przyciagającymi uwagę reklam, dla części osób, stanowił także kolor. Co siedemnasty, w badanej zbiorowości, wyraził opinię, że zainteresowany jest głównie występowaniem w reklamach znanych osobistości. Wpływ celebrytów był zdecydowanie większy wśród osób z przedziału 18-24 lat niż konsumentów starszych, co potwierdza się także w badaniach Tyszki (2004).

Rodzaj elementów zamieszczanych w reklamach, które najskuteczniej przekonywały ankietowane osoby do zakupu towarów przedstawia rysunek 3.

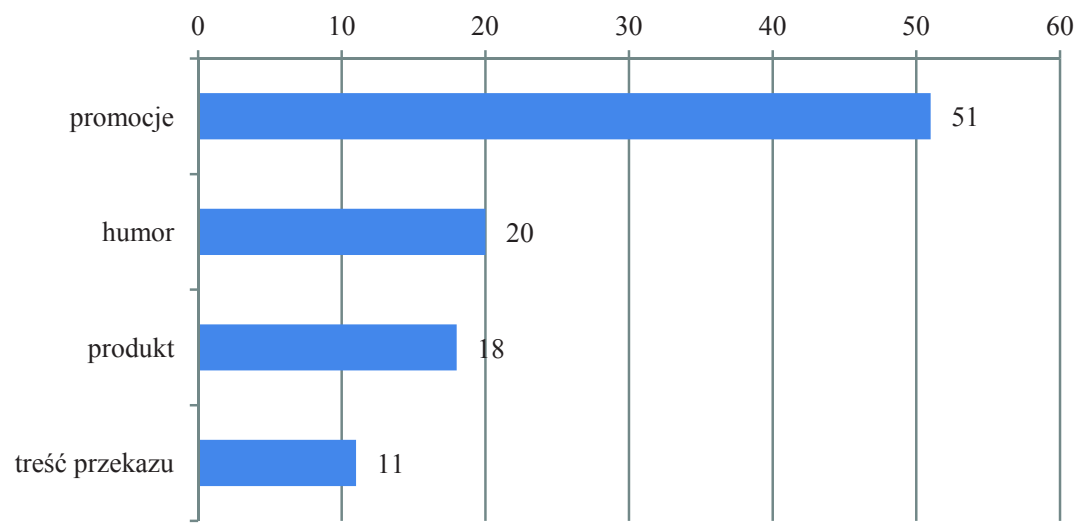

Rys.3. Elementy reklamy najskuteczniej przekonujące do zakupu produktu (\%wskazań)

Fig. 3. Advertising elements most persuasive for a product purchase ( $\%$ indications)

Źródło: obliczenia własne na podstawie przeprowadzonego badania ankietowego.

Na podstawie udziału wypowiadających się należy stwierdzić, że najskuteczniejszym elementem przekonującym do zakupu określonego dobra, dla ponad połowy badanych, były promocje zawarte w reklamach. Co piąta osoba zwracała uwagę na ciekawy humor zawarty w przekazie reklamowym, stwierdzając, że on stanowił zasadniczy bodziec do realizacji zakupu reklamowanego produktu. Na uwagę zasługuje fakt, że motyw humoru zdecydowanie przeważa nad innymi elementami, gdyż jego znaczenie podkreśliło aż 63\% rodaków w ogólnopolskich badaniach (Nowacki, 2012). Dla kolejnych 18\% ankietowanych główną determinantą skłaniającą do nabycia reklamowanego wyrobu był sam produkt. Natomiast dla osób stanowiących najmniejszy odsetek wyrażających swoje zdanie na omawianą kwestie były treści zawarte w przekazach reklamowych.

Ważnym zagadnieniem $\mathrm{w}$ przeprowadzonych badaniach było także określenie jak duże znaczenie mają reklamy w podejmowaniu decyzji zakupu towarów przez mieszkańców obszarów wiejskich badanego województwa. Strukturę wypowiedzi na ten temat prezentuje rysunek 4. 


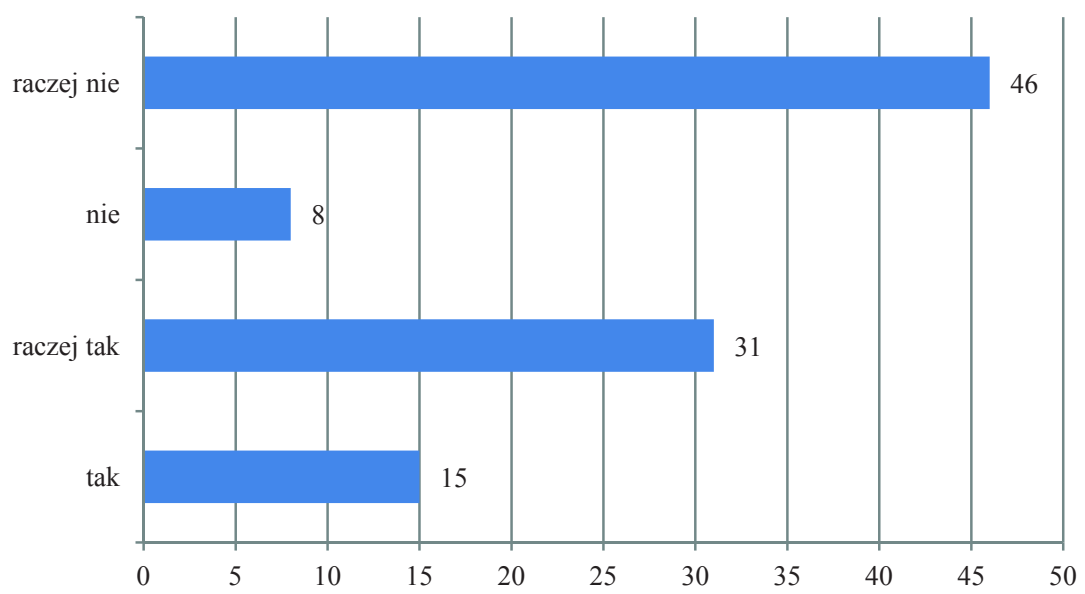

Rys. 4. Znaczenie reklam w decyzjach zakupu dóbr badanych konsumentów (\% wskazań)

Fig. 4. The importance of advertising in decisions of surveyed consumers to purchase goods (\% of indications)

Źródło: Obliczenia własne na podstawie przeprowadzonego badania ankietowego

$\mathrm{Na}$ podstawie uzyskanych wyników badań należy stwierdzić, że łącznie dla 46\% ankietowanych reklamy mają wpływ na podejmowanie decyzji o zakupie produktów, w tym dla co siódmego - zdecydowanie tak. Także opinię wyraziło także 26\%respondentów, w badaniach przeprowadzonych przez Cyrka (2015), którzy uważali, że towary, na reklamę których producenci przeznaczają znaczne nakłady finansowe muszą cechować się wysoką jakością. Jednoznacznie negatywną opinię wyraziło $8 \%$ badanych. Największy udział w całej zbiorowości stanowili ci, których wypowiedzi z pewnym wahaniem zaprzeczały wpływowi reklam na zakup towarów.

\section{Wpływ reklam na zakup towarów przez konsumentów z obszarów wiejskich woj. podkarpackiego}

Jako konsument, każdy człowiek, jest poddawany wpływowi działań reklamowych. Znaczącym jest jednak fakt, że ze względu na indywidualne cechy i upodobania nabywców inaczej przez każdą osobę odbierane są reklamy, w związku z czym zróżnicowane są reakcje i siła wpływu na podejmowanie decyzji zakupowych. Rodzaj nabywanych produktów i usług pod wpływem reklam, przez badanych mieszkańców gmin wiejskich woj. podkarpackiego przedstawia rysunek 5.

$\mathrm{Z}$ danych zaprezentowanych na rysunku wynika, że pod wpływem reklam najwięcej badanych konsumentów nabywało artykuły żywnościowe. Decydują o tym zwłaszcza treści reklam artykułów spożywczych, co potwierdzają także zagraniczni autorzy Harris, Bargh, Brownell (2009) oraz Boyland, Halford (2013), które maja wpływ na zachowania żywieniowe ich odbiorców, co w znacznym stopniu wynika ze specyfiki rynku żywności. Prawie co szósty wypowiadający się, sugerując się przekazem reklamowym dokonywał zakupów sprzętu gospodarstwa domowego i elektronicznego, a co siódmy zaopatrywał się 
w artykuły chemii gospodarczej. Co ósmy ankietowany, udzielający odpowiedzi, oświadczył, że reklamy ukierunkowują go do zakupu kosmetyków, a co dziewiąty stwierdził, że do korzystania z usług bankowych. Co dziesiątemu reklama pomagała w zaopatrzeniu się w odzież i obuwie. Wśród udzielających odpowiedzi znalazły się także osoby, które pod wpływem przekazów reklamowych korzystały z usług medycznych oraz decydowały się na zakup mebli. W tym ostatnim przypadku był to jednak najniższy odsetek ankietowanych.

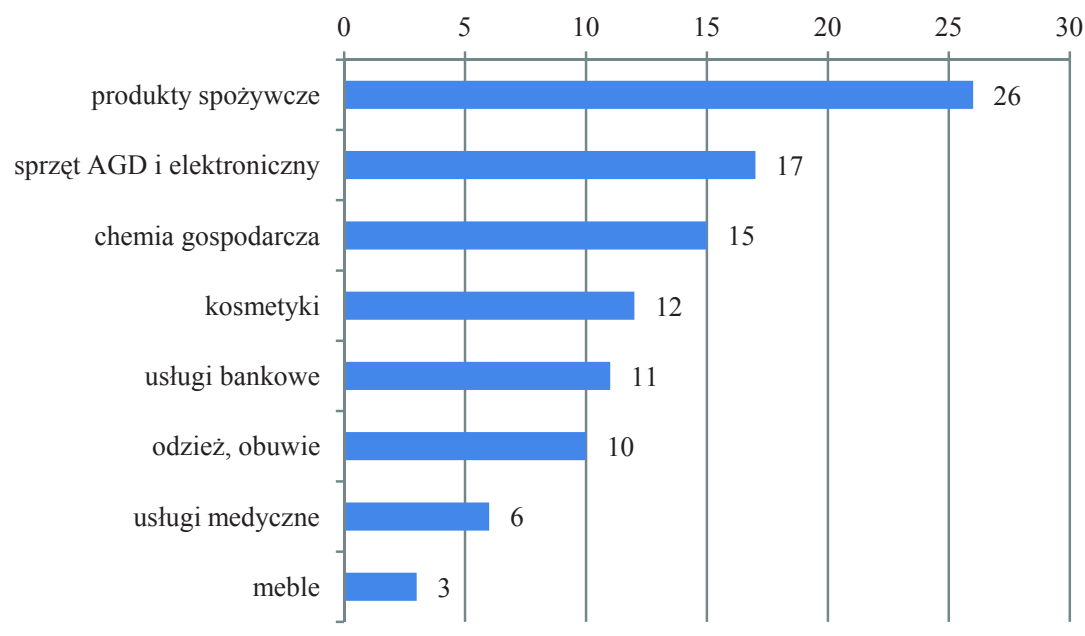

Rys. 5. Produkty i usługi najczęściej kupowane przez badanych konsumentów pod wpływem reklam (\% wskazań)

Fig. 5. Products and services most often bought by surveyed consumers under the influence of advertising ( $\%$ of indications)

Źródło: obliczenia własne na podstawie przeprowadzonego badania ankietowego.

Do oceny skuteczności oddziaływania reklam na ich odbiorców wykorzystano wypowiedzi dotyczące zakupu zbytecznych produktów pod wpływem reklam. Taki rozwój wydarzeń pozwala na potwierdzenie, że przekazy reklamowe są efektywne gdyż potrafią zachęcić do zakupu i wypróbowania towarów. W tabeli 1 przedstawiono strukturę wypowiedzi ankietowanych dotyczących zakupu niepotrzebnych produktów, wyłącznie pod wpływem przekonującej reklamy.

Z tabelarycznych danych wynika, że wśród ogółu nabywających zbędne artykuły pod wpływem reklamy prawie 54\% stanowili ci, którzy rzadko zachowywali się w ten sposób. W drugiej kolejności występowali konsumenci, którzy nigdy nie nabywali produktów pod wpływem przekonujących reklam. Prawie co siódmej osobie ankietowanej zdarzało się to często. Natomiast zakup bardzo częsty dotyczył minimalnego odsetka wyrażających się na ten temat. Analizując zagadnienie według płci należy zauważyć, że niepotrzebne zakupy pod wpływem reklam dokonywały w większym stopniu kobiety niż mężczyźni, a wskaźnik negatywny na rzecz kobiet występuje zwłaszcza w odniesieniu do realizacji częstych zakupów niepotrzebnych dóbr. To zróżnicowanie stylów decyzyjnych występujących między kobietami a mężczyznami wynika $\mathrm{z}$ faktu traktowania przez kobiety zakupów $\mathrm{m}$. in. jako formy rozrywki, podczas gdy mężczyźni traktują zakupy utylitarnie, czyli jako 
konieczność zaspokojenia potrzeb (Budzanowska-Drzewiecka, 2015). Odnosząc się do zachowań badanych według wieku największe różnice są zauważalne pomiędzy najmłodszymi a najstarszymi wiekiem konsumentami. Polegają one na tym, że aż 14,3 pkt. proc. wyższy był wskaźnik młodszych nabywców od starszych, którzy nigdy nie zakupili zbytecznych towarów pod wpływem reklam. Na korzyść osób najmłodszych przemawia również fakt, że o 9,3 pkt. proc. niższy był wskaźnik częstych realizacji tego rodzaju zakupów od osób powyżej 60 roku życia.

Tabela 1. Odsetek wypowiedzi badanych konsumentów na temat zakupu zbytecznych towarów pod wpływem przekonującej reklamy (\% wskazań)

Table 1. Percentage of statements of surveyed consumers on the purchase of superfluous goods under the influence of convincing advertising ( $\%$ indications)

\begin{tabular}{|c|c|c|c|c|c|}
\hline \multirow{2}{*}{ Wyszczególnienie } & \multicolumn{5}{|c|}{ Częstotliwość zakupu artykułów zbytecznych } \\
\hline & ogółem & nigdy & rzadko & często & bardzo często \\
\hline Płeć: & & & & & \\
\hline - kobieta & 100,0 & 18,0 & 58,0 & 22,7 & 1,3 \\
\hline - mężczyzna & 100,0 & 40,8 & 53,9 & 5,3 & - \\
\hline Wiek (lata): & & & & & \\
\hline$-18-24$ & 100,0 & 37,5 & 50,0 & 12,5 & - \\
\hline$-25-39$ & 100,0 & 26,0 & 62,0 & 12,0 & - \\
\hline$-40-59$ & 100,0 & 35,8 & 51,7 & 12,5 & - \\
\hline - 60 i więcej & 100,0 & 23,2 & 53,1 & 21,8 & 1,9 \\
\hline
\end{tabular}

Źródło: obliczenia własne na podstawie przeprowadzonego badania ankietowego.

Kolejne zagadnienie dotyczyło sprawdzania przez konsumentów rzeczywistych właściwości reklamowanych nowych produktów wprowadzanych na rynek, co prezentuje struktura wypowiedzi przedstawiona na rysunku 6

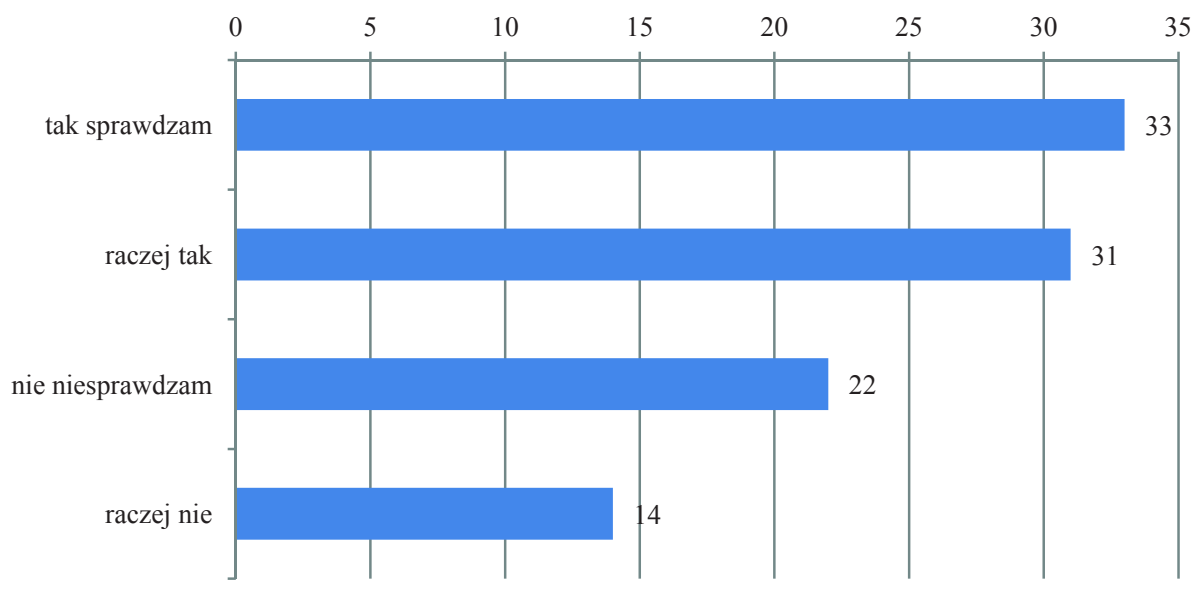

Rys. 6. Opinia ankietowanych na temat sprawdzania właściwości nowych, reklamowanych produktów (\% wskazań)

Fig. 6. Opinion of respondents on checking the properties of new, advertised products (\% indications)

Źródło: obliczenia własne na podstawie przeprowadzonego badania ankietowego. 
Zgodnie z uzyskanymi wynikami badań przewagę stanowiły osoby (łącznie 64\%), które sprawdzają reklamowane nowe dobra pod względem ich rzeczywistych właściwości. Co czwarta osoba wśród badanych wypowiedziała się, że ufa reklamie i zupełnie nie odczuwa potrzeby sprawdzania właściwości produktu przed jego zakupem. Również 14\% ankietowanych „raczej nie” ma potrzeby. Okazuje się zatem, że wśród ankietowanych łącznie $36 \%$ uznawało reklamę za wiarygodną. Należy zauważyć, że jest to znacznie wyższy odsetek $\mathrm{w}$ porównaniu $\mathrm{z}$ wynikami badań zaprezentowanymi $\mathrm{w}$ artykule Jaski (2014), w którym taką opinię wyraził co dziesiąty respondent.

\section{Wnioski}

Dla mieszkańców gmin wiejskich woj. podkarpackiego najważniejsze znaczenie miały reklamy zamieszczane w telewizji i Internecie, charakteryzujące się przede wszystkim oryginalnością i walorami estetycznymi.

Podkład muzyczny i elementy wizualne były najbardziej interesujące w odbiorze przekazów reklamowych dla badanej zbiorowości. Natomiast największy, bo $51 \%$ był udział tych konsumentów dla których promocje zawarte w reklamie najskuteczniej przekonywały do realizacji reklamowanych produktów.

Znaczenie reklam w podejmowaniu decyzji o realizacji zakupu określonego produktu miało jednoznaczny wpływ dla prawie co siódmego ankietowanego konsumenta, a dla $31 \%$ „raczej tak”.

Pod wpływem reklam najwięcej mieszkańców obszarów wiejskich woj. podkarpackiego kupowała artykuły spożywcze, sprzęt gospodarstwa domowego i sprzęt elektroniczny, w minimalnym stopniu natomiast meble. Ankietowani zwrócili uwagę na korzystanie z usług bankowych (11\% wskazań) oraz usług medycznych $(6 \%)$ pod wpływem reklam. Wśród ankietowanych występowały osoby (ponad 15\%), które pod wpływem reklam często nabywały niekoniecznie potrzebne produkty. W tym przypadku wyróżniały się zwłaszcza kobiety, których udział wyniósł prawie 23\%, mężczyzn natomiast tylko $5 \%$. Świadczy to o tym, że kobiety były bardziej podatne na reklamy i pozytywnie do nich nastawione.

Większość ankietowanych mieszkańców gmin wiejskich (64\%) sprawdzała reklamowane nowe produkty pod względem rzeczywistych ich cech. Natomiast $36 \%$ badanych wyraziło opinię, że ufa reklamom i nie odczuwa potrzeby sprawdzania produktów.

\section{Literatura}

Bednarek, M. (2014). Bednarek podsumowuje rynek reklamy (Bednarek sums up the advertising market). Brief $\mathrm{z}$ dn. 9.01.2014 r.

Boyland, E.J., Halford, J.C.G. (2013). Television advertising and branding: effects on eating behawior and food preferences in children. Appetite, 62, 236-241.

Budzanowska-Drzewiecka, M. (2015). Style podejmowania decyzji zakupowych przez młodych konsumentów w Polsce w świetle badań własnych (Styles of purchasing decisions made by young consumers in Poland in the light of own research), Handel Wewnętrzny, 1(354) 50-59. 
Cyrek, P. (2015), Opakowanie jako źródło informacji o produktach żywnościowych (Packaging as a source of information about food products). ZN Uniwersytetu Szczecińskiego, Seria Problemy Zarzadzania Finansów i Marketingu, 39, 9-21.

Doliński, D. (2010). Psychologiczne mechanizmy reklamy (Psychological mechanisms of advertising). Gdańskie Wyd. Psychologiczne, Gdańsk.

Gędek, M. (2013). Reklama. Zarys problematyki (Advertisement. Outline of the problem). Wyd. KUL, Lublin.

Harris, J. L., Bargh, J. A., Brownell, K. D. (2009). Proming effects of television food advertising on eating behawior. Health Psychology, 28(4), 404-413.

Jaska, E. (2014). Wpływ reklamy na postawy konsumentów jako element budowania przewagi konkurencyjnej przedsiębiorstw (The impact of advertising on consumer attitudes as an element of building a competitive advantage of enterprises). Handel Wewnętrzny, 1(354), 125-129.

Kozłowska, A. (2014). Model oddziaływania reklamowego: weryfikacja dotychczasowych założeń (Advertising impact model: verification of existing assumptions). ZN Uniwersytetu Szczecińskiego, Seria Problemy Zarzqdzania Finansów i Marketingu, 36, 279-294.

Małysa-Kaleta, A. (2010). Procesy globalizacji i integracji jako uwarunkowania zachowań konsumentów [w:] Konsument i jego zachowania na rynku europejskim (Processes of globalization and integration as determinants of consumer behavior [in:] Consumer and his behaviour on the European market), Red. E. Kieżel, Polskie Wydawnictwo Ekonomiczne, Warszawa.

Mazurek-Łopacińska, K. (2001). Polscy konsumenci w drodze do Unii Europejskiej [w:] Zachowania podmiotów rynkowych w Polsce a proces integracji europejskiej. (Polish consumers on a way to the European Union [in:] Behaviours of market players in Poland and the process of European integration). Red. Z. Kędzior, K. Karcz, Akademia Ekonomiczna, Katowice.

Nowacki, R. (2012). Innowacyjność działań reklamowych - przejawy i skutki (Innovativeness of advertising activities - indications and effects). ZN Uniwersytetu Szczecińskiego, Seria Problemy Zarzadzania Finansów i Marketingu, 26, 55-70.

Nowacki, R. (2013). Percepcja przekazów reklamowych i jej wpływ na zachowania konsumentów w pierwszej dekadzie XXI wieku (The perception of advertising messages and its impact on consumer behaviour in the first decade of the 21st century). ZN Uniwersytetu Szczecińskiego, Seria Problemy Zarzqdzania Finansów i Marketingu, 32, 403-416.

Peszko, K. (2014). Wybory reklamodawców w świetle badań - wiodące i tracące na popularności nośniki reklamowe (The choices of advertisers in the light of research - advertising media gaining and losing on popularity). ZN Uniwersytetu Szczecińskiego, Seria Problemy Zarzadzania Finansów i Marketingu, 36, 331341.

Rudnicki, L. (2009). Determinanty zachowań konsumentów na rynku (Determinants of consumer behaviour on the market). Państwowa Wyższa Szkoła Zawodowa w Nowym Saczu, Nowy Sącz.

Sowa, I. (2010). Czynniki demograficzne determinujące zachowania konsumentów [w:] Konsument i jego zachowania na rynku europejskim (Demographic factors determining consumer behaviour [in:] Consumer and his behaviour on the European market). Red. E. Kieżel, Polskie Wydawnictwo Ekonomiczne, Warszawa.

Tyszka, T. (2004). Psychologia ekonomiczna (Economic psychology). Gdańskie Wydawnictwo Psychologiczne. Sopot.

Do cytowania / For citation:

Grzybek M., Szopiński W. (2018). Znaczenie reklamy w postrzeganiu i kształtowaniu decyzji zakupowych konsumentów z gmin wiejskich województwa podkarpackiego. Problemy Rolnictwa Światowego, 18(3), 134-143; DOI: 10.22630/PRS.2018.18.3.72

Grzybek M., Szopiński W. (2018). The Importance of Advertising in the Perception and Shaping of Purchasing Decisions of Consumers from Rural Communes of the Podkarpackie Province (in Polish). Problems of World Agriculture, 18(3), 134-143; DOI: 10.22630/PRS.2018.18.3.72 